\title{
Why I became a chemistry teacher: identifying turning points in chemistry teacher narratives of their trajectories into teaching.
}

\author{
Alexander J Dawes and Ruth Wheeldon* \\ UCL Institute of Education, UCL, London, UK \\ *Corresponding author: Email: r.wheeldon@ucl.ac.uk
}

Background: Currently there are international concerns over teacher recruitment and attrition rates, especially in mathematics and the physical sciences. Much has been written about the recruitment of student teachers and the reasons people give for going into teaching, but little on the broader context of these people's lives and the complex influences on their career decisions.

Purpose: The narrative approach used in this study is a complement to larger scale quantitative studies into teacher recruitment as it seeks to consider the wider picture of a person's life and, through a defended participant perspective, expose influences that may not have been obvious to the participants themselves.

Sample: Eight current UK chemistry teachers

Design and methods: Stories of becoming teachers are told through interviews and these narratives examined to consider the key influences upon their becoming chemistry teachers. Two analytic lenses were used: inductive thematic analysis and deductive analysis considering psychoanalytical defences. These lenses were used to both exemplify and challenge each other, providing triangulation of interpretation to determine participants' trajectories into chemistry teaching.

Results: Family background and interest in, and utility of, studying chemistry were found to influence career life decisions. Some participants experienced moments where their career trajectory changed towards teaching whereas others followed a smooth path towards this end. For two, changes in their relationship with chemistry resulted in a teaching career. Particularly 
influential appears to be prior teaching experience which led to changes of trajectory for half of the participants in this study.

Conclusion: The chemistry teachers' relationship with the subject discipline and prior teaching experience were important in them entering the profession, whilst the influence of their own teachers is more nuanced than wider larger scale quantitative studies suggest. Findings suggest that increasing the opportunity for classroom experience for undergraduates may improve teacher recruitment.

Keywords: chemistry teaching; recruitment; STEM; narrative; Nimier defences.

\section{Introduction}

\section{A shortage of Science (STEM) teachers}

There is a potential crisis in many countries around the world in terms of future teaching numbers. For example, in Sweden (Lindqvist, Nordänger and Carlsson 2014) this shortfall could reach twenty percent by 2020 . Teachers leaving the profession within the first five years is a huge problem in countries like Sweden, the USA and the UK (both $30-50 \%$ ), but interestingly far less so in France and Germany (around 5\%) (Cooper and Alvarado 2006).

The lack of enthusiasm by Science, technology, engineering and Mathematics (STEM) graduates for a teaching career in some countries may be a direct result of the general shortage in STEM professionals, increasing the number and type of highstatus and lucrative career options available to graduates in those fields, thereby exacerbating the difficulties of attracting new graduates and career switchers into teaching STEM subjects (Harris and Jensz 2006). If other STEM careers are seen as more desirable, and at the heart of national agendas, then a lack of qualified teachers to potentially inspire the next generation is a likely consequence resulting in a decline 
in young people participating in tertiary STEM education. This decline has been seen in the USA over the last 2 decades (Watt, Richardson, and Pietsch 2007), resulting in grave concern about the viability of these disciplines to sustain economic growth and development (Jacobs 2005).

There is less research data specifically regarding Chemistry teachers, but as a discipline falling under the STEM banner it is likely to mirror the picture described above. In the context of this study, data from the UK indicates that less than one third of high school students in England are taught chemistry by a teacher with a strong chemistry subject background (DfE 2013).

Studies into the recruitment of science teachers focus on the reasons given by the trainee teachers and much less data is available regarding the reasons given by those teachers who are in teaching positions. In this paper, narrative accounts given by chemistry teachers at different stages of their teaching careers are used to consider the nuanced factors which affected their becoming chemistry teachers.

\section{Influential Factors in teacher recruitment}

Heinz (2015) argues that it is important to understand the motivations of student teachers and what attracts them to teach in the first place. The wider literature, including the large US meta-analysis by Brookhart and Freeman (1992), suggests that there are three main sources of motivations influencing the decision to enter initial teacher training: intrinsic, altruistic and extrinsic.

Intrinsic motivations include factors such as the enjoyment of teaching, job satisfaction, creativity and an interest in chosen teaching subject(s). Studies around the world have shown these factors as the most influential, including various UK studies (Reid and Caudwell 1997; Thornton, Bricheno, and Reid 2002; Younger et al 2004). Altruistic reasons for going into teaching include a sense that teaching is useful 
and socially worthwhile and that going into the profession will contribute on an individual level to young people but also to society as a whole (Richardson and Watt 2006). Extrinsic reasons to go into teaching include 'aspects of the job which are not inherent in the work itself, such as status of the profession, levels of pay, holidays as well as job security, transferability, and flexibility' (Heinz 2015, 267).

Other influential factors Heinz (2015) has identified include student teachers' teaching-ability related beliefs, their prior teaching and learning experiences, the potential influence of family members and others and the impact of socio-cultural factors, such as cultural, religious or ethnic identity. An idea prevalent in the international literature (Brookhart and Freeman 1992; Heinz 2013; Lortie 2002; Richardson and Watt 2006; Watt and Richardson 2007; Younger et al. 2004) is that high levels of confidence in their own teaching ability relates mostly to their confidence in their subject knowledge and/or character traits they observed in their own best teachers.

Another issue is that of opportunity; for many people deciding to teach may not be as simple as something they have intrinsic, altruistic or extrinsic motivation for, but rather an opportunity that presents itself according to market forces with an individuals' 'choice of teaching over other available occupations' (Guarino, Santibanez, and Daley 2006, 175).

If we can understand the motivations for training to teach more clearly, then teacher training and newly qualified teacher schemes could and should align themselves with these, whilst addressing the tension between these aspirations and the reality in the classroom, as called for by Heinz (2013) and Priyadharshini and Robinson-Pant (2003). 


\section{Theoretical Framework}

\section{Identity and Narratives}

Identity is a complex and problematic term, much considered by philosophers and in the wider literature, including within the educational field. Beliefs in some kind of core-self have been challenged; is it possible to remain the same person when so much of the body biochemically changes? Nietzsche, argued against the idea of a core-self but considers people as a combination of different forces and drives, something that Freud utilises in his development of psychoanalysis (Freud 1964). In more recent times, memory, aligned with our desires, intentions, beliefs and temperaments have been considered to combine into some kind of personal identity (Parfit 1984). Current debates refer to the idea that identity is constructed and that it is developed and shaped by our relations with external factors. The teacher education literature agrees that identity is 'dynamic, and that a teacher's identity shifts over time under the influence of a range of factors both internal to the individual, such as emotion, and external to the individual, such as job and life experiences in particular contexts' (Beauchamp and Thomas 2009, 177).

Here, the construction of the chemistry teacher identity and how that shifts and is shaped is considered as a trajectory, where stories about choices in their lives reveal how they see themselves as who they are, as part of the narrative they construct of this process (Goodson et al.2010).

Sfard and Prusak (2005) suggest that the significant narratives about a person can be split into two subgroups: actual identity, consisting of stories about how things are, and designated identity, consisting of narratives presenting a state of affairs which, for one reason or another, may be the case, if not now, then in the future. Designated identities give direction to how one acts and can influence one's deeds. 
Here both the current chemistry teacher actual identity and the designated identities from accounts about journeys into chemistry teaching can be considered from the expressed self-beliefs and the sources of these beliefs along their trajectory into teaching.

The Eccles model (Eccles et al. 1983) identifies and maps the components that affect educational choices by linking achievement-related beliefs, outcomes and goals to interpretive systems like casual attributions, to the input of socialisers (parents, teachers, siblings, peers and the media) to various social-role related beliefs, to self-perceptions and self-concept, and to one's perceptions of various tasks, behaviours and activities themselves. Using aspects of this model and their relationship with STEM subjects and careers, Bøe et al. (2011) conclude that teachers are key actors in the effort to increase participation in STEM education and careers. However, the Eccles model draws largely on quantitative survey data which does not locate these perceptions with the wider life context of the person. This has led to a call to move towards more qualitative research that explores how the students themselves handle and make meanings of their choices (Holmegaard, Madsen and Ulriksen 2015). Research carried out since 2000 (Holmegaard 2015; Holmegaard, Madsen and Ulriksen 2012), looking at how students' identities relate to their choice of education has found that for the students it is not only a question about what they want to study but also of who they wish to become: that is of constructing an attractive identity. Therefore, this research aims to examine chemistry teacher narratives to note how they construct their chemistry teacher identity.

\section{Identity and 'The defended Self'}

In contrast to the above inter-psychological lens of identity considering external 
factors identified as those influencing changes, an intra-psychological lens which views the participant as having an identity that is relatively fixed which the individual seeks to protect against external forces can also be used. This idea of defended subjects has developed from the work of Melanie Klein, who in contrast to Freud's model of psycho-sexual development (Waddell 2002), views the self as characterised by 'positions' or 'states of mind' which invoke particular defences, anxieties, and types of relationship with others.

Klein developed theories as to two particular states of mind which are separate in the way they shape our understanding of the world and ourselves: the paranoidschizoid position and the depressive position (Segal 2012). The chief characteristic of the paranoid-schizoid position is the splitting of both self and object into good and bad, with little or no integration between them, such that people and events are experienced either as unrealistically wonderful (good) or as unrealistically terrible (bad)'. Anxiety focuses around self-protection (Waddell 2002). Usually at the ages of three to six months, a child is thought to move to the depressive position, characteristically bringing together conflicted feelings of love and hate, realising the hated person and the loved person are one and the same, such that anxieties regarding the other object now arise. Earlier in life the child is thought to take a paranoidschizoid position or none at all. This conflict is repeatedly revisited throughout early childhood, and intermittently throughout life, moving between the two states depending upon the situation the individual finds themselves in. Nimier (1993) developed Klein's defence mechanisms, into a framework of phobic defences which displace anxieties and therefore contain these anxieties by keeping away from objects causing these; and manic defences which use the same object to defend from within against anxiety elsewhere. Typical phobic defences relevant to studying chemistry 
would include it being difficult, remote, not relevant or interesting, all reasons to avoid the subject. Chemistry being creative, useful, helpful or enjoyable are manic defences of it which help defend us from anxieties such as those around continuing to study it. In this study, the participants expressed feelings are examined in terms of these Nimier defences.

Together these two lenses aim to answer the following research questions:

- What are the key influences on chemistry teachers' trajectories into the profession?

- What do participants reveal about their identity with regards to chemistry and teaching when describing this trajectory?

- What can we learn about chemistry teacher recruitment from considering their narratives?

\section{Methods}

Data were collected via narrative interviews and analysed inductively. Narrative accounts were then further analysed to note the potential use of the 'defended self', Nimier (1993) defences. How the participants defend their self-identities regarding their choice to study chemistry and to teach are examined. This allows comparison of the reasons given with the nuanced way those reasons are presented. Detail of each of these methods is given below:

\section{Narrative Interviews}

The seven interviews were carried out over the course of two academic years (201416) and were informal conversational in style. Prior to each participant's interview they were informed that the research topic was chemistry teaching and chemistry 
teachers but not further specifics. The interviews were deliberately not structured extensively because the intention was to elicit the participants' narratives, as far as was possible, the way they wished to tell them (Hollway and Jefferson 2000).

Each interview was begun with a control statement (Stylianou 2008), 'I'm interested in talking to people about the story of how they became to be a teacher", which in most cases led the participant to ask where they should begin, whereupon they were told they could begin wherever they wished. The First author (Alex)'s own narrative of becoming a fellow chemistry teacher was also collected via a written account. This written narrative was analysed in the same way as the transcribed interviews.

\section{Participants}

A convenience sample consisted of five chemistry teacher colleagues from the first author's place of work, a London mixed state comprehensive faith school (School A), and two chemistry teachers from another nearby mixed state comprehensive school (School B), who Alex did not know beforehand and had never worked alongside. It is not uncommon to interview one's colleagues within educational studies and 'insider' status, which provides an ability to empathise with them and the pressures and demands on their time, may allow for more open responses during interviews (Adriansen and Madsen, 2009). Different professional relationships change this potential openness but that the interviewer is directing proceedings around specific foci also gives power dynamics which are difficult to account for (Kvale, 2006). These power relationships will have had an influence on the interviews, as is often noted, and participants may attempt to give the answers that they perceive the interviewer wishes to hear. In this study, the use of the Nimier defence analysis 
offered the opportunity to consider inconsistencies in the stories presented to the interviewer (likely to be affected by the points noted) and the way motivations to teach chemistry are expressed and therefore consider a more nuanced sense of the motivations for choices. Table 1 provides information about each participant.

\begin{tabular}{|c|c|c|c|c|c|}
\hline $\begin{array}{c}\text { Name } \\
\text { (Pseudonyms } \\
\text { except First } \\
\text { author) }\end{array}$ & Gender & $\begin{array}{c}\text { Years teaching } \\
\text { (at time of } \\
\text { interview) }\end{array}$ & $\begin{array}{c}\text { Years known to } \\
\text { interviewer (at time } \\
\text { of interview) }\end{array}$ & $\begin{array}{l}\text { Length of } \\
\text { interview } \\
\text { (minutes) }\end{array}$ & $\begin{array}{c}\text { School taught } \\
\text { at }\end{array}$ \\
\hline Aaron & $\bar{M}$ & 2 & 2 & 21 & School A \\
\hline Alex & M & 19 & (interviewer) & $\begin{array}{c}\text { Not } \\
\text { applicable }\end{array}$ & School A \\
\hline Claire & $\mathrm{F}$ & 3 & 3 & 31 & School A \\
\hline Joshua & M & 30 & 19 & 18 & School A \\
\hline Richard & M & 1 & 1 & 31 & School A \\
\hline Sachin & M & 16 & 0 & 25 & School B \\
\hline Sara & F & 10 & 0 & 21 & School B \\
\hline Sonia & $\mathrm{F}$ & 25 & 2 & 38 & School A \\
\hline
\end{tabular}

Table 1. Participants

\section{Ethical considerations}

Informed consent is a cornerstone of ethical behaviour, as it respects the rights of individuals to exert control and make their own decisions (Howe and Moses, 1999). It was recognised there was a possibility that by identifying the school from the first author's identity, it would be possible to speculate about teacher identities even when pseudonyms would be used and this raised concerns for interviewees' possible discomfort or embarrassment. This possibility was made clear in consent letter 
information and at interview and a summary of the main points discussed provided to the interviewee for them to verify and potentially withdraw consent if they wished.

\section{Analysis}

The audio-recordings and transcripts (and written narrative) were repeatedly reviewed and compared until consistent influencing themes were noted, where they represented some level of patterned response across the participants (Braun and Clarke 2006). Here the influencing themes emerged inductively which began to form hypotheses which were used to interrogate further interview data. These themes are given in the findings section, Table 3. Suitable excerpts from the participants are presented which are illustrative of the theme but also detailed enough to provide context for the reader.

When constructing the 'defended self' analysis, a similar strategy was taken looking to identify particular manic and phobic defences, or their counters. Here Rodd's (2010) application of Nimier's six defences to mathematics as a subject are adapted to examine the participants' defences or supports for choosing or rejecting chemistry and teaching. The six defences (and counters) as applied to chemistry and teaching are given in Table 2.

Type purpose positions

\begin{tabular}{|c|c|c|}
\hline \multirow{3}{*}{ Phobic } & \multirow{3}{*}{$\begin{array}{l}\text { Defend self-identity by not } \\
\text { choosing chemistry/teaching }\end{array}$} & Avoid: remote/difficult \\
\hline & & Meaningless: not relevant/interesting \\
\hline & & Dangerous: bad to project myself onto it \\
\hline \multirow{3}{*}{$\begin{array}{l}\text { Not- } \\
\text { phobic }\end{array}$} & \multirow{3}{*}{$\begin{array}{c}\text { Supports for choosing } \\
\text { chemistry/teaching (and self- } \\
\text { identity) }\end{array}$} & Approach: good at it/ easy \\
\hline & & Enjoy: relevant/interesting \\
\hline & & Beneficial: safe \\
\hline \multirow{3}{*}{ Manic } & \multirow{3}{*}{$\begin{array}{l}\text { Defend self-identity by choosing } \\
\text { chemistry/teaching }\end{array}$} & Creative: useful \\
\hline & & Good for me: helps me/gives skills \\
\hline & & Comfort: gives me joy/comforting \\
\hline \multirow{2}{*}{$\begin{array}{l}\text { Not- } \\
\text { manic }\end{array}$} & & Useless: not creative \\
\hline & & Bad for me: does not help me \\
\hline
\end{tabular}


Supports for not choosing

chemistry/ teaching (and self identity)

Anxiety making: gives no comfort

Table 2: Positions using phobic and manic defences (and their counter supports) regarding Chemistry/Teaching

Each narrative was examined for any of these positions and then their use compared to the overall story such that nuanced meanings could be drawn out. For example, when enjoyment of and interest in chemistry was expressed alongside anxiety regarding continuing study of it, indicating that the chemist identity was not a fully comfortable one. Here the social circumstances given in the narrative allowed the potential changes in and influences on the chemistry teacher identity trajectory to be considered.

\section{Findings}

\section{Thematic Findings}

Four influential themes emerged from multiple readings of the interview transcripts and written account given in Table 3.

\section{Influences}

Parents. Parental influence on life choices varied being more overt in the cases of Aaron and Sachin:

my grandfather's a doctor, my father's a doctor, young Aaron too shall be a doctor (Aaron) 


\begin{tabular}{|c|c|c|c|}
\hline \multirow{3}{*}{ Parents } & \multirow[b]{2}{*}{ Educational: } & \multirow{2}{*}{$\begin{array}{c}\text { Subject choice } \\
\text { Choice to } \\
\text { study at } \\
\text { Undergraduate } \\
\text { level } \\
\end{array}$} & \multirow{2}{*}{$\begin{array}{c}\text { Claire, Alex } \\
\text { Alex, Sachin, Sonia }\end{array}$} \\
\hline & & & \\
\hline & \multicolumn{2}{|c|}{ Career } & $\begin{array}{l}\text { Aaron, Richard, Joshua, } \\
\text { Sonia }\end{array}$ \\
\hline \multirow{2}{*}{ Teachers } & \multicolumn{2}{|c|}{ Subject choice } & Alex, Sonia, Claire \\
\hline & \multicolumn{2}{|c|}{ Interest/ enjoyment } & Alex, Sonia, Claire \\
\hline \multirow[b]{2}{*}{ Chemistry } & \multicolumn{2}{|c|}{ Interest } & Alex, Sara, Sachin, Claire \\
\hline & \multicolumn{2}{|c|}{ Utility } & $\begin{array}{l}\text { Richard, Joshua, } \\
\text { Aaron (lesser extent) }\end{array}$ \\
\hline \multirow{2}{*}{$\begin{array}{l}\text { Teaching } \\
\text { experience }\end{array}$} & \multicolumn{2}{|c|}{ In school } & $\begin{array}{l}\text { Sara, Sachin, } \\
\text { Claire (primary) }\end{array}$ \\
\hline & \multicolumn{2}{|c|}{$\begin{array}{l}\text { wider experience with high } \\
\text { school aged pupils }\end{array}$} & $\begin{array}{l}\text { Aaron (youth groups), } \\
\text { Alex (sport coaching) }\end{array}$ \\
\hline
\end{tabular}

Table 3: Influences identified by thematic analysis

I think probably having a dad who was a technician in a school and having a mum who was also a technician in a school, so having that connection was always surrounded by science and surrounded by school and education talk and growing up with that; it was always a thing that I was around, so I chose science A levels, they weren't actually the subjects I did best in.... I felt that I had more of an interest in the sciences. (Sachin)

Whereas, for Claire and Alex a picture of support emerges, although within a general expectation of gaining a high level of education:

when I told them I didn't want to do medicine anymore, and become a teacher, and drop down from a Masters and do a PGCE they were really supportive and they said, actually I think that is the right thing; I think you'd be well suited to that. They said whatever you want to do, we'll support you and so I don't think they've had a huge influence on me, but they've been very supportive. (Claire) 
All the participants expressed support demonstrated by their parents, but expectations appeared to vary subtly from a drive towards education to a drive towards a career goal. This, in turn, influenced where Chemistry fitted in, as a goal itself for Alex and Claire, but part of the pathway for the others.

Teachers. All the participants talk about some of their teachers at school, but not always their Chemistry teachers, overall positively. However, in the stories they told about becoming Chemistry teachers, their own teachers were sometimes influential in taking the subject further, but not so much in terms of becoming teachers themselves.

I felt my Chemistry teacher was my 'best' teacher and his dry sense of humour and strictness certainly appealed to me, but I think it was always inherent in the subject that I was interested, the balance between doing, thinking and making links that most attracted me. I knew I would study chemistry at university (Alex).

I got on really well with my chemistry teacher at college and he's the one who influenced me, my passion for chemistry (Claire).

Chemistry. Relationships with the subject itself also vary, from intrinsic passion expressed by Alex and Claire, towards utility of the subject expressed by Richard and Joshua.

I should have done maths, but I really liked chemistry and I said to my parents I want to study something I enjoy if I'm going to spend three years doing it. I'd rather sit for days on end reading chemistry text books and understanding something than maths. I like maths but I'm not that interested in it (Claire).

If you want someone who can crunch data, interpret data, look at graphs, you know, explain to people using very simplistic language to explain something, get a physicist, get a chemist, get an engineer who will do a lot of a better job than anyone else. (Richard) 
Teaching experience. Prior teaching experience was a pivotal part of the story that two participants gave. Both Sara and Sachin spent time in secondary schools whilst studying at university. Sara says:

I absolutely loved the atmosphere and that was it really. It sold it to me, I walked into school and it was crazy. ... I said that's what I want to do with the rest of my whatever... (Sara)

I really, really loved it there, and then got into third year of the degree and kind of had that as an idea at the back of my head, maybe this could be something that I do (Sachin)

\section{The defended self}

Defences and supports for choosing chemistry

All defences and supports for choosing chemistry are summarised in Table 4. 
Positions using phobic and manic defences (and their counter supports) regarding Chemistry (if used once -used, if used more than once - some, if used consistently -consist.)

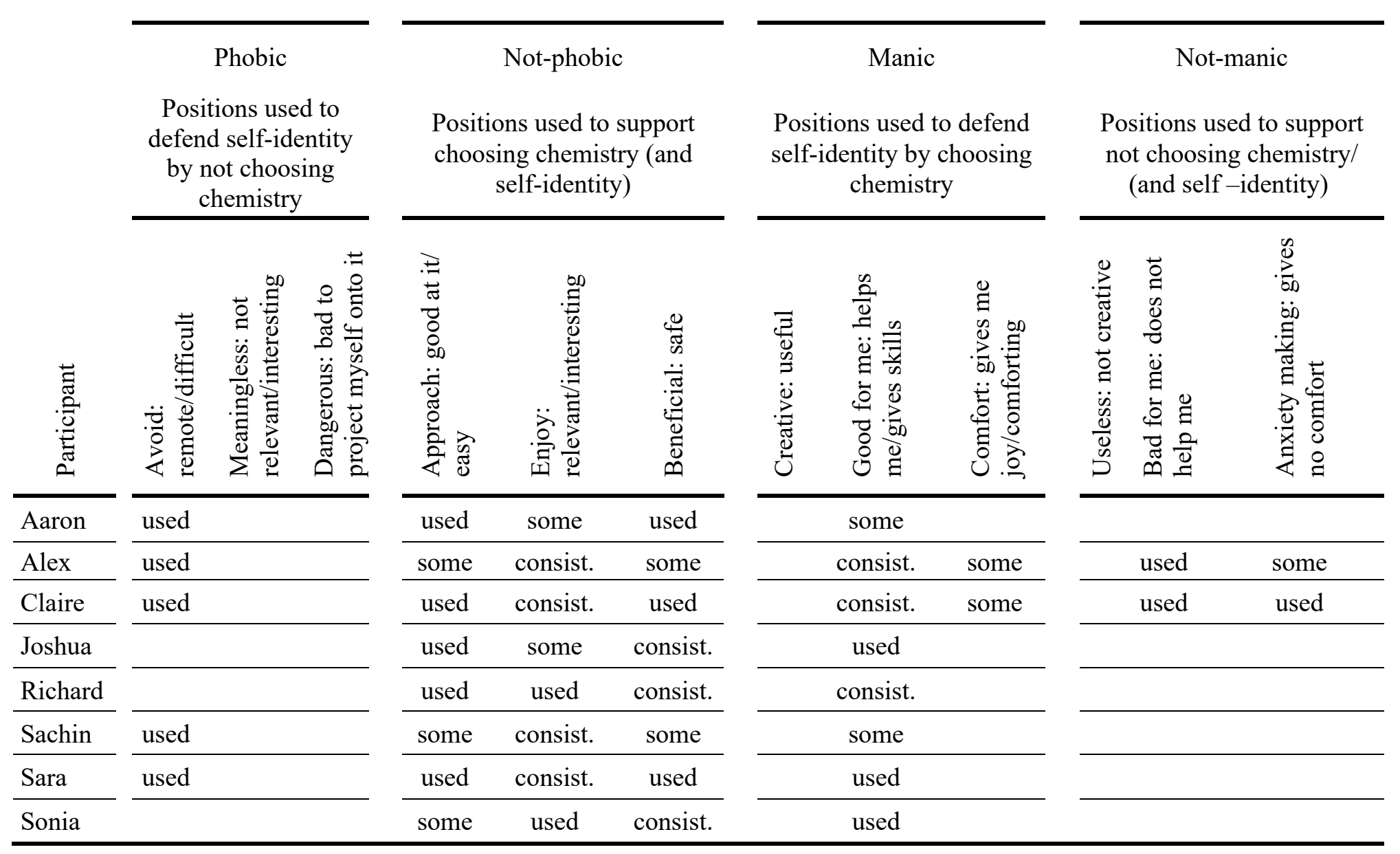

Table 4: Positions using phobic and manic defences (and their counter supports) regarding Chemistry 
'I think I loved it from the first day I had a name to pin to it' stated Alex.

Claire said, 'I really enjoyed chemistry... So that's why I did chemistry at uni - really enjoyed it.' Both suggest an inherent joy in learning chemistry in these narratives that is not identified in the other participants' narratives. Most of the participants express their interest in the subject in terms of other things. Both Sara and Sachin express their interest in chemistry rationally rather than emotionally, Sara against the backdrop of her siblings having studied chemistry and Sachin in relating chemistry to his other subjects:

We all [Sara and her siblings] ended up doing chemistry degrees, so I went to [university] to do my chemistry degree and I really enjoyed the chemistry. (Sara)

They weren't actually the subjects I did best in, I did better in my history and my geography and my French and all that, but I felt that I had more of an interest in the sciences. (Sachin, describing choosing A-levels ${ }^{1}$ after $\mathrm{GCSE}^{2}$ results)

Richard defends his decision-making process differently by defending his interest in science/chemistry against both mathematics and aspirations to study at Cambridge University:

There were two reasons I haven't mentioned [for studying science]. The first was that I really wanted to go to Cambridge; I knew I wasn't good enough to do maths there. Or I was scared if I wasn't good enough [for] there, I would be left with little option, so I went for the subjects that I had a better chance in, chemistry and physics, and natural sciences at Cambridge. At school, it was a lot

\footnotetext{
${ }^{1}$ A-Levels are advanced high school examinations sat in England and Wales which are used for University selection. Pupils usually study 3-5 subjects at advanced level.

${ }^{2}$ GCSE - General Certificate of Secondary Education - national qualifications in England and Wales usually gained from examinations sat at age 16.
} 
easier for me to score well in chemistry exams than it was in maths exams, doing the same amount of work. (Richard)

Richard seems to express a love of mathematics which then cannot fulfil aspirations he has for himself as he gets older; it becomes harder, more time consuming and his perceived competition for a place at Cambridge begins to intimidate him. This move to present the physical sciences more positively is simultaneous to the presentation of mathematics as something to be avoided, through a non-manic defence of his identity as being good at chemistry.

Joshua mentions an interest in all his studies and that choosing the sciences was largely a consequence of the way things were done at his school:

My A level choice was dictated by the fact that the school decided that if you could do science you did, so I did, and then the choice was that whether you did biology or maths with your physics and chemistry. (Joshua)

Joshua also uses the words passive and disinterested to describe his decisionmaking process, as well as saying that his choices were dictated to him. None of the other seven participants use words like this to describe how they made further study decisions, they defend their decisions with either an interest in learning about the subject or with what it could do for them in the future. Richard and Joshua both identified with different academic subjects in early secondary school, but both go on to study chemistry at university and then to become chemistry teachers.

\section{Defences and supports for choosing teaching}

The defences and supports for choosing teaching are summarised in Table 5. 


\begin{tabular}{|c|c|c|c|c|c|c|c|c|c|c|c|c|}
\hline \multirow[b]{4}{*}{ 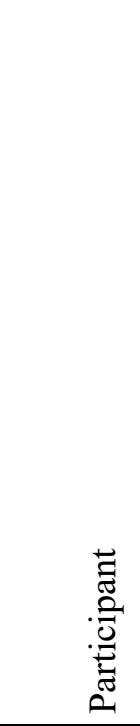 } & \multicolumn{12}{|c|}{ Positions using phobic and manic defences (and their counter supports) regarding Teaching } \\
\hline & \multicolumn{12}{|c|}{ (if used once -used, If used more than once - some, If used consistently -consist.) } \\
\hline & \multicolumn{3}{|c|}{$\begin{array}{l}\text { Phobic } \\
\text { Positions used to defend self- } \\
\text { identity by not choosing } \\
\text { teaching }\end{array}$} & \multicolumn{3}{|c|}{$\begin{array}{c}\text { Not-phobic } \\
\text { Positions used as supports for } \\
\text { choosing teaching (and to } \\
\text { support self-identity) }\end{array}$} & \multicolumn{3}{|c|}{$\begin{array}{l}\text { Manic } \\
\text { Positions used to defend self- } \\
\text { identity by choosing teaching }\end{array}$} & \multicolumn{3}{|c|}{$\begin{array}{l}\text { Not-manic } \\
\text { Positions used as supports for not } \\
\text { choosing teaching (to protect self- } \\
\text { identity) }\end{array}$} \\
\hline & 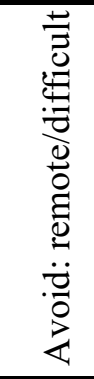 & 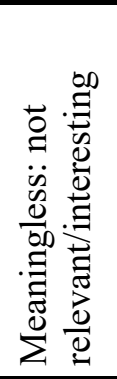 & 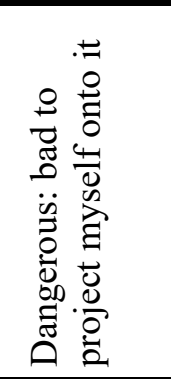 & 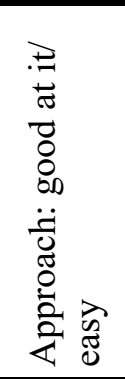 & 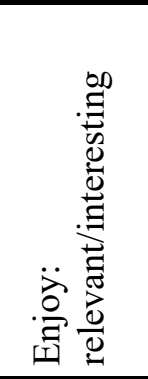 & 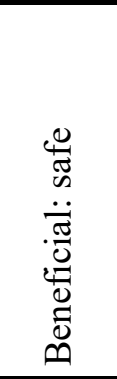 & 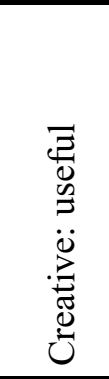 & 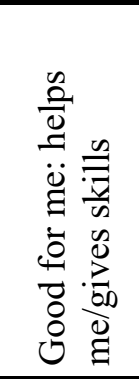 & 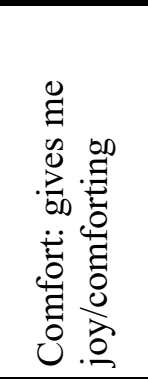 & 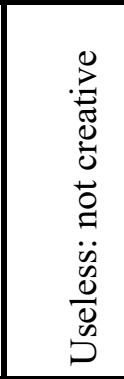 & 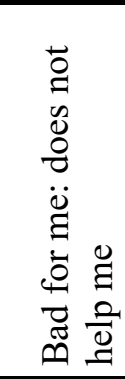 & 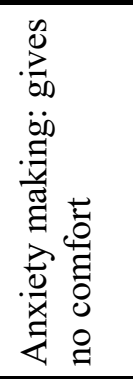 \\
\hline Aaron & & & & some & & & & & used & & & \\
\hline Alex & & & & & & some & & consist. & some & & & \\
\hline Claire & & & & & & some & & some & some & & & \\
\hline Joshua & & & & & consist. & some & & & some & & & \\
\hline Richard & & & & some & some & & & some & used & & & \\
\hline Sachin & & & & & consist. & & some & & consist. & & & \\
\hline Sara & & & & & consist. & & some & & consist. & & & \\
\hline Sonia & & & & & & some & & & & & & used \\
\hline
\end{tabular}

Table 5: Positions using phobic and manic defences (and their counter supports) regarding Teaching 
As the participants talked about their decision to teach, they all expressed some rejection of other options such as chemistry research, working in industry or the city. Some, like Alex and Claire, do so in terms of chemistry causing anxiety whereas others do so in terms of a rejection of a particular lifestyle.

Being an average/mediocre chemist and surrounded by very talented students was on one hand a great experience and on the other, rather hard to deal with. Any confidence I had gained from doing well at school and gaining a place at the institution [Oxford University] was tempered by the reality of the ability of many of my friends and the gap I perceived between them and myself. In fact, I performed perfectly acceptably at Oxford but I came to the conclusion that I wasn't of PhD material. (Alex)

I think in terms of carrying on, I don't think I was good enough to carry on maybe. I could have done a Masters but wasn't good enough for a PhD. I think I'd hit my limit at a Bachelor's. (Claire)

Both Claire and Alex position themselves relative to others in terms of chemistry itself. Both were highly successful in their schooling, but within their university cohort they made comparisons which were less flattering. None of the other participants express any anxiety caused by chemistry but do give other reasons for not taking it further.

From participants' narratives it was apparent that most use teaching to defend life choices made previously in some way. Richard, Claire and Alex say they enjoy teaching and it gives happiness but concentrate on what it does for them directly (introjection), whereas Sachin and Sara defend themselves narcissistically in terms of the joy their work gives them through helping others:

...but the practice in the classroom, I was absolutely ecstatic about it. Really enjoyed it just getting involved and being able to pass on that knowledge and that love of the subject. (Sachin) 
I just went in there and taught and absolutely loved it. .. (Sara)

Interestingly, unlike Richard and Joshua or Claire and Alex, this desire is because of an experience of teaching as opposed to an aspiration earlier in life or a rejection of post-graduate science, which potentially illustrates how some people could be attracted to teach in the future.

\section{Discussion}

In this section the findings are discussed in terms of how they provide answers to each of the research questions and relate to the wider literature.

\section{What are the key influences on chemistry teachers' trajectories into the profession?}

As any trajectory into chemistry teaching requires the choice to continue with Chemistry study and also the choice of teaching as a career, influences on those participant choices are considered below.

Deciding to study chemistry:

As noted above interest in the subject itself, parents and teachers are influential here.

The participants in the current study give accounts of their good teachers as inspirational with regards to subject matter matching Moore's (2004) review findings of dominant discourses in teaching and teacher education describing good teachers as charismatic subjects, competent crafts persons and reflective practitioners.

...just his passion for the subject was in every lesson and that made me really passionate about it and from really early on I said chemistry was my favourite subject. (Claire)

I can think of particular teachers now who were very memorable, less so the science teachers interestingly enough, although there was one particular 
chemistry teacher who was just brilliant, inspirational, whose strongest piece of advice was, whatever you do, don't become a teacher... He helped me to enjoy chemistry. (Joshua)

Sara also talks positively about her science teachers although within the confines of an already established hierarchy of inter-subject ranking:

I really liked chemistry obviously, that was my favourite subject. Biology I didn't like so much, it was one of my harder subjects as I couldn't remember a lot of the content but the teachers, I remember the teachers, and that was quite inspiring, the teachers that came in to teach. (Sara)

For Sonia, the influence of her inspiring teacher includes directing her away from further study in their subject.

I had this fabulous history teacher, he was a Cambridge graduate and he was a very great teacher but I think, in those days they were quite misinformed about what you needed to have to go to university; they assumed because they had had their very upper class education, that everybody had to have the Latin and the French and the languages to do history and I guess I thought that perhaps because I hadn't done French and I hadn't done Latin it wouldn't be the right path for me to take. (Sonia)

For Aaron, a more negative picture is presented with Chemistry emerging victorious, almost by default, in terms of grades obtained, which he lays squarely at the doors of his teachers.

I had dropped out of Physics because, probably because I didn't get on with the teacher so well. (Aaron)

I had a B in Biology and, as a teacher, I am reluctant to do this but I still happily will blame the teacher on this occasion. (Aaron) 
Munro and Elsom (2000) found that pupils' motivation towards and enjoyment of science, through their experience of science in the classroom and through extracurricular activities, was significantly influenced by teachers and contributed to pupils' choice of further science study, which is in keeping with the comments noted above. Similarly, such teacher influence over further study choice is noted even more strongly by undergraduates compared with their school pupil counterparts by Powers and Myers (2017).

\section{Deciding to teach}

Lack of expressions of altruistic motivations to teach chemistry was surprising when considering that this is often noted as the single most important type of motivation (Fray and Gore, 2018). However, much research indicating this has come from preservice teachers and studies into motivations for a teaching career and retention show that intrinsic motivations support longer teaching careers. This study involves those who have taught for longer and that intrinsic motivations such as their love of their subject and enjoyment of teaching are most important to these in-service teachers as noted by McLean, Taylor, and Jimenez (2019).

As noted above teachers are not credited here with influencing the decision to teach. However, FIT-choice scale survey responses credit teachers with influencing the decision to teach (Watt and Richardson 2007). Perhaps the direct questioning of the role of teachers results in respondent's conflating their choice of subject for higher level study with their choice to teach, which in the interviews conducted here can be considered separately. Furthermore, Department for Education Commissioned research (CooperGibson Research 2018) also drawing from interviews with UK teachers found as for many in this study, that they related their choice to teach directly 
to experience with young people and or teaching experience of some sort or a knowledge of teaching from family members.

\section{What do participants reveal about their identity with regards to chemistry and teaching when describing this trajectory?}

Bringing together the influences, defences, supports and their overall effects, four different trajectories are identified. The narratives give timeline trajectories which show turning points toward teaching which are associated with 'defences or supports' of self -identity around studying chemistry and becoming a teacher choices.

\section{I became a teacher because I always wanted to be one}

Joshua stated that he wished to be a teacher from a young age, at primary school, and this desire did not diminish until he finally realised his goal after university.

\footnotetext{
When I became a teenager, I sort of thought I wanted to go into teaching but I didn't know what it was going to be like so decided that I wouldn't do a B.Ed. qualification, I'd get a degree then do teacher's training and my A level choice was dictated by the fact that the school decided that if you could do science you did, so I did, and then the choice was that whether you did biology or maths with your physics and chemistry. That was the way that it operated in the school I went to. (Joshua)
}

This trajectory (Figure 1) is different to that of the rest of the participants. He only uses manic defences of his teacher identity around enjoyment of teaching. Otherwise he expresses only supports for his interest and enjoyment of chemistry and for his decision to teach. For him this teacher self-identity was established early and his narrative is consistent with this identity. As Brooks (2016) points out in her book about geography teacher identity, some people just want to teach. These people are on a steady trajectory towards teaching from a young age and for potential secondary 
school teachers like Joshua, the subject they will teach is almost incidental to this trajectory, which is not to say that the subject is not important but for Joshua the subject was determined by what he was good at and what his school allowed.

As the narrative accounts allowed approximate time frames for these choices to be identified as for Joshua above, participants' trajectories into chemistry teaching are represented in the figures presented in this section, by noting the timings of these choices in terms of education or post education years. Trajectory shifts or gradual movement toward continuing with chemistry study to a graduate level and considering teaching as a suitable career are shown as deviations from a zero level trajectory (not into chemistry teaching) up to training to teach as the highest point.

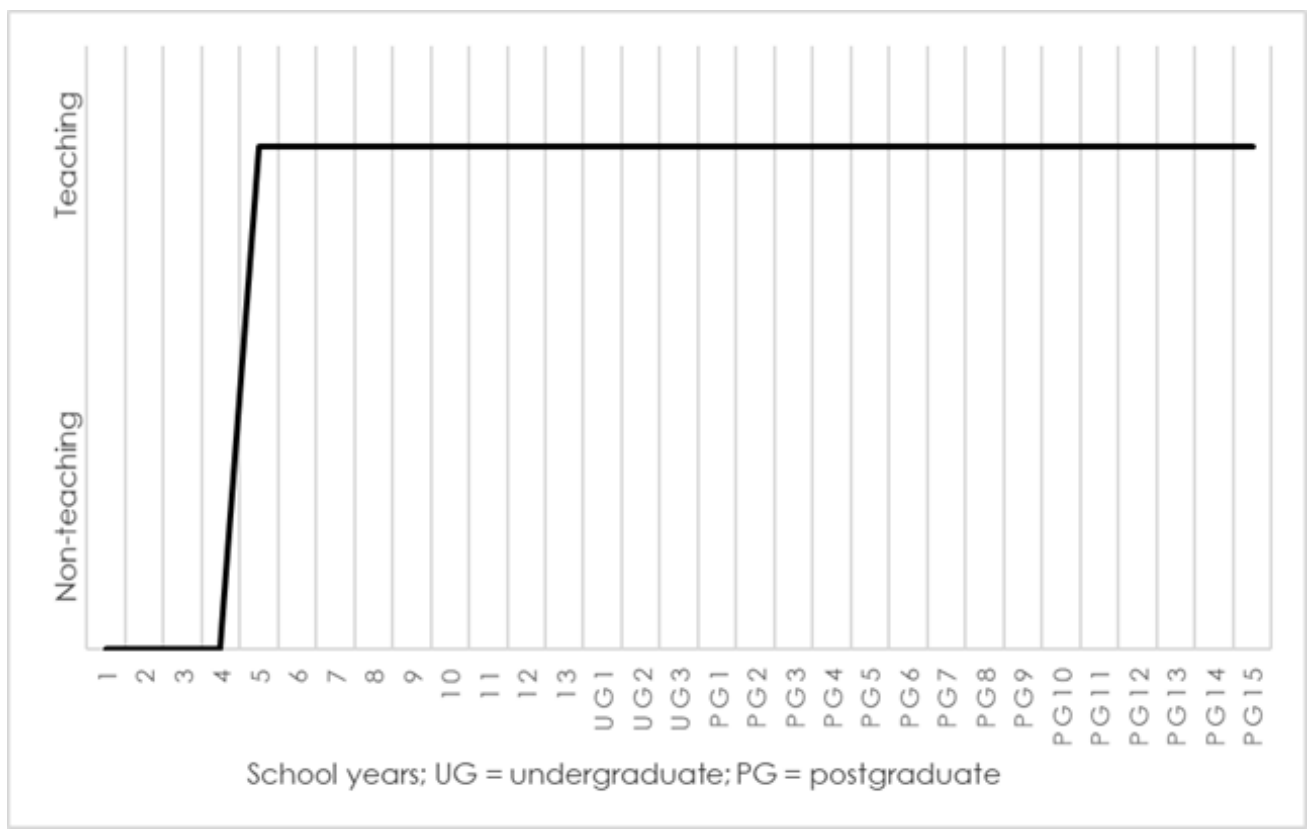

Figure 1: 'I became a teacher because I always wanted to be one' trajectory into teaching. 
I became a chemistry teacher because I thought I couldn't continue as an academic chemist and wanted to continue in chemistry

Alex and Claire give phobic and manic defences as well as supports for choosing chemistry which are expressed regarding post graduate study alongside manic defences of the joy they gain from teaching.

They gave no stated desire to teach until they reached midway through their undergraduate studies when both rejected postgraduate science studies in favour of teacher training. This was a major turning point in their lives where both changed their academic aspirations, in Alex's case from doing a science $\mathrm{PhD}$ and in Claire's from staying on to do her master's degree (Fig.2). The need to defend the self from harmful phobic positions regarding choosing further chemistry study despite their supports of it as providing joy, is in direct tension with manic needs to maintain a chemistry self-identity. This turning point in the latter part of undergraduate studies might occur with many students, particularly science students, where the proportion who go on to further academic study or research is high compared with other disciplines (Redman et al. 2013).

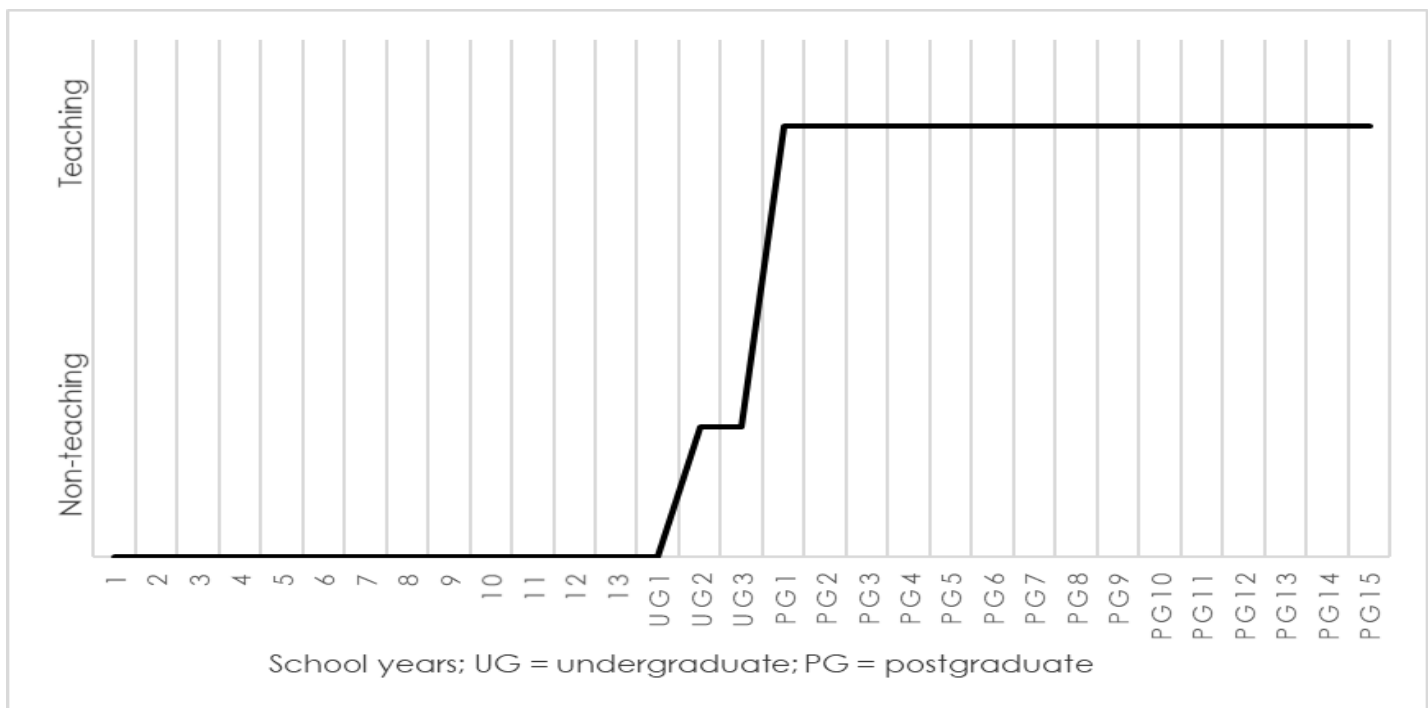

Figure 2: 'I became a chemistry teacher because I thought I couldn't continue as an academic chemist and wanted to continue in chemistry' trajectory into teaching. 
Both Claire and Alex indicate that they became teachers to remain close to their subject, the utility and manic joy of chemistry is maintained without the phobic concerns associated with further chemistry study. For them an emphasis on the chemistry part of the chemistry teacher identity is important. This is something in common with two of Brooks' (2016) Geography subjects, whose subject knowledge influenced their teacher identity strongly. Furthermore, Glutsch and König (2019) have found that in Germany pre-service teachers rated subject-specific interest as the most important factor for their choice to teach. This major turning point may be an opportunity missed for other students who reject further study, in the same way Claire and Alex did, but do not consider teaching as an alternative.

\section{I became a teacher because I always wanted to be one, but after I had established myself economically}

Richard expressed a wish to teach whilst at secondary school, but with the clear intention to do other things first, which he did do during a career in the city of London. Nevertheless, years later, he stuck to his original plan and undertook teacher training. Richard, like Joshua, makes manic defences of his choice to study chemistry but this is expressed alongside a stronger manic enjoyment and support of mathematics. Here the stronger manic defence of his choice is in terms of Chemistry's utility. Again Richard's manic defence of his choice to teach also matches his supports but for him the trajectory in his narrative is complicated by his need for economic security. This is mirrored by Anthony and Ord's (2008) New Zealand based study of career changing pre-service teachers which found 28 of 68 participants said that they had previously considered teaching at an earlier stage in their lives. For various reasons these people had found themselves working in other jobs but had retained the desire to teach when circumstances, especially family circumstances, were more favourable. Although Richard, in some ways, was as driven to teach as Joshua, his turning point, after ten years working as a trader in the financial markets, 
depended on Richard being able to organise his own affairs, financially and administratively, so that he felt he could resign his well-paid job and train to teach. Had he not been able to do so, it is unlikely he would not have made this change. Therefore, this turning point is less easy to directly compare to others as it is so dependent on a multitude of factors and individual circumstances (Fig.3).

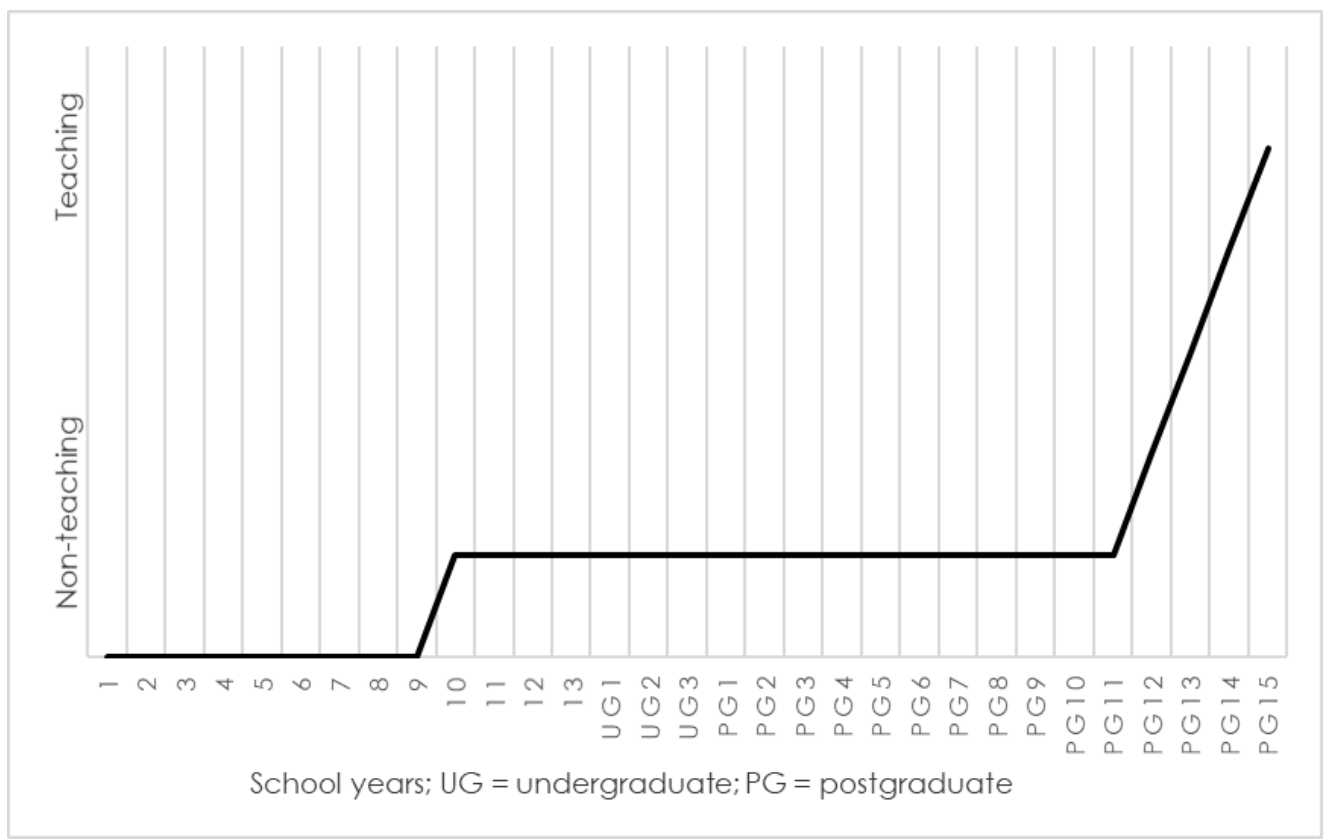

Figure 3: 'I became a teacher because I always wanted to be one, but after I had established myself economically' trajectory into teaching.

I became a teacher after school experience or youth work presented the possibility

For most participants the manic defences of joy/utility from the teaching or youth experience appears as the strong influence into teaching chemistry. Sonia, however, although also having a turning point into teaching around teaching experience, doesn't express any manic defences for her teaching, rather she presents only supports for this decision.

Sonia showed little desire to teach throughout school and university but began to earn some money teaching whilst completing her $\mathrm{PhD}$ which led her to undertake a 
teacher training qualification subsequently, despite it never having been a particular desire of hers. Of all the participants Sonia gave the least impression of wishing to teach, rather it is fitting the bill at a time in her life where she needed to work post$\mathrm{PhD}$. Without stating it outright, she gave the largest indication of an extrinsic motivation to teach; she needed a break from academic life after her $\mathrm{PhD}$, so first took an administrative role away from family pressure in London, then saw a teaching career as a logical next step and, despite preferring to teach at primary level, she trained as a secondary school chemistry teacher due to a place being available (having missed the deadline for primary training application). This also was compatible with the idea of having children in the future. Therefore, she is not considered to be on a trajectory towards teaching at all until the utility value of teaching became clear to her. Sonia does not express a particular love of the subject nor a drive to teach. This difference in motivations to teach has been identified by Thomson, Turner and Nietfeld (2012) who identified three typologies of motivation profiles for teaching: Enthusiastic, Conventional for whom altruistic and intrinsic motivations dominate and also the Pragmatic typology where extrinsic motivations around the life 'fit' of teaching as a career is a significant motivation. Sonia fits this Pragmatic profile well, as her reasoning is notable against her lack of defence for her decision.(Fig.4).

During my degree there was a scheme, at my university... You could volunteer to go in there [local secondary school] and for one afternoon a week you would work with science classes or maths classes in those schools. You'd be like an extra pair of hands or a tutor... absolutely loved it, absolutely loved it, it was highlight of my week... and then got into third year of the degree and kind of had that as an idea at the back of my head, maybe this could be something that I do ... (Sachin)

I had done my week working, spent the week at the science department... The kids were crazy, it one of those really weird surreal moments when you think this 
is amazing, crazy kids but they have got inspiring teachers, I don't even know who they are. They just stood up there and got the class silent and in control and I said that's what I want to do with the rest of my whatever... (Sara)

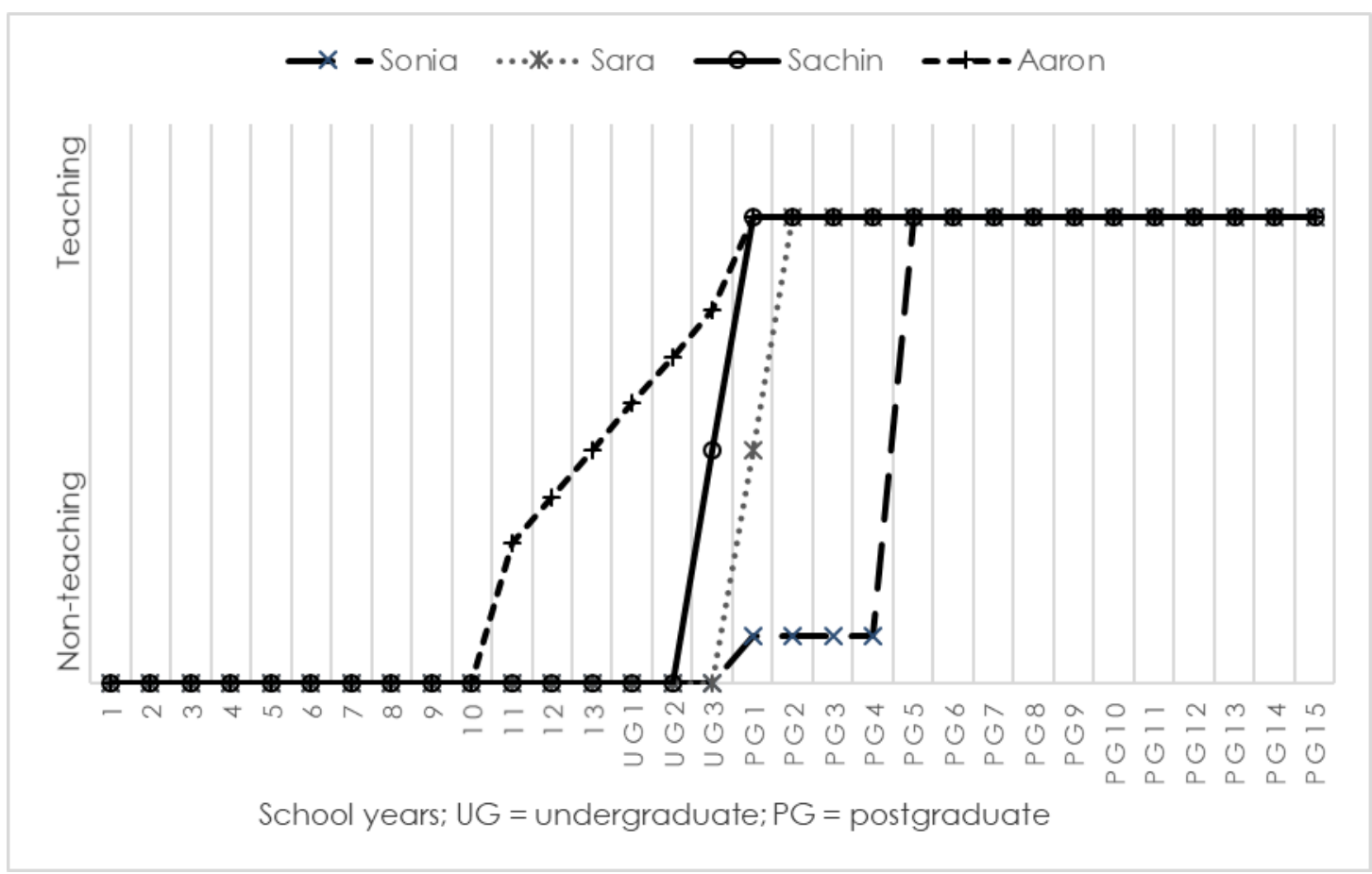

Figure 4: 'I became a teacher after school experience or youth work presented the possibility' trajectory into teaching.

Sara and Sachin both showed little desire to teach as they went through their school and university studies. However, they both had a major turning point, Sachin in his final year as an undergraduate when he took part in a scheme that placed students in local schools and Sara when she organised work experience in a school in the first year of her postgraduate studies. These turning points took two successful chemistry students directly into relatively long and successful careers as chemistry teachers (Fig.4). Both express consistent manic joy with their experiences of working with young people and that joy is similarly expressed consistently regarding their choice to teach. Similarly, a US study of preservice teachers identified $8.3 \%$ were 
motivated to teach by their previous experience of teaching (Reeves and Lowenhaupt, 2016) and so this is an experience upon which to consider potential teaching ability identified as another highly significant motivational factor (Watt and Richardson, 2008, 2012; Watt et al., 2012). Without the opportunities that were available to them at this juncture of their education, it is not certain that either of them would have followed this path.

I had done some teaching at... plus youth work as well, so it was something I knew that I enjoyed and basically thought well why not give it a punt? ... I am enjoying teaching science; I am enjoying teaching chemistry. (Aaron)

Aaron similarly expresses limited manic defence of his teaching choice with some supports and in his narrative he does relate his experience in youth work to becoming a teacher. He had already rejected the academic science world, despite his first-class chemistry degree, as his passion was not in this direction. It was for wider learning and his prior experience led him to teach as the logical consequence. This experience of relationships with children or young people are reported by large numbers of student teachers across subjects as having had an important influence on their decisions to become a teacher in the UK (Malderez et al. 2007).

\section{What can we learn about chemistry teacher recruitment from considering their narratives?}

For some people teaching has been a life aim. These teachers set out on a trajectory with this goal (Figs. 1 and 3). For these potential teachers it is important to support them in remaining on this track by providing viable, suitable and flexible routes into the profession is, whatever their age. Good teacher training and early career mentoring is essential for the profession to live up to this life goal, as international literature points to this problematic gap between career motivations and actual 
experiences in the classroom (Brookhart and Freeman 1992; Heinz 2013; Lortie, 2002; Richardson and Watt 2006; Watt and Richardson 2007; Younger et al. 2004)

For others, the trajectory to becoming a teacher involved turning from a different career path already embarked upon. Two important turning points have been noted here: when during undergraduate or postgraduate study the trajectory to becoming an academic/research chemist is thwarted or when a chance opportunity to experience teaching led to this career change (Figs. 2 and 4).

\section{Limitations}

This is a very small study which is localised both in terms of the UK, and London, although its broad conclusions are applicable to other countries like Australia, Canada and the US where similar debates persist.

Generalising from this extremely small sample was never the intention of this study, but instead it sought to investigate influences on its participants' career trajectories and examine what we can learn from these.

\section{Conclusions and Implications}

\section{Need for more Chemistry teachers:}

People choose to study chemistry, both at school and beyond, for a variety of reasons but two factors dominate: an interest in and joy from learning about the subject and a sense that studying it has utility. Chemistry, as an academic discipline, has cache (Mujtaba and Reiss 2014; Sheldrake 2016) as a respected and challenging subject to study, as a gatekeeper to many 'successful' careers and one that will be seen in a good light irrespective of what you choose to do with it. Teachers are influential in encouraging interest or engagement with their subject and thus encourage further study (Powers and Myers 2017). However, in countries, like the UK where there is a 
shortage of specialist chemistry teachers then this opportunity is already diminished (Royal Society of Chemistry 2014) leading to a further reduction in the supply of chemistry graduates for teaching.

Therefore, an important implication of this research is to advocate an increase in schemes that allow undergraduates access to school experience, not necessarily teaching but experiencing the classroom from the educator's perspective, something called for by Hillier, de Winter and Twidle (2013) in the case of physics. There is international evidence that undergraduate students are eager for potential avenues of employment to be 'embedded within the curriculum' (Ogunde et al. 2017, 469). One participant, Sara explained the benefit of such an experience succinctly: "I absolutely loved the atmosphere and that was it really. It sold it to me". Schemes such as the Student Associate Scheme (SAS) ${ }^{3}$ have long existed in the UK as well as student ambassadors ${ }^{4}$ being placed into schools by organisations like the Royal Society of Chemistry and universities. Advocating this time in the classroom for most undergraduates may result in some of them having a less than positive experience, but this is potentially just as useful. 93\% of Student Associates indicated that their experiences on the Scheme had equipped them to make better informed decisions about a career in teaching and for two thirds their experience on the Scheme had encouraged them to pursue a career in teaching (McCrone, et al. 2020).

Here the aspiration is to open up the world of the classroom to undergraduates because otherwise the only other way to judge a potential teaching career is one's own

\footnotetext{
${ }^{3} \mathrm{SAS}$ is a UK undergraduate scheme providing classroom experience as a module contributing to the degree.

${ }^{4}$ Student Ambassadors, visit schools encouraging STEM uptake and recruitment to universities
} 
experience of being a school student and personal opinions of teaching and teachers, influenced by friends and family, as well as promulgated in the media. If students were able to judge their interest in teaching more effectively this may result in an improvement in teacher recruitment numbers.

\section{Value of narrative research contributions}

Quantitative methodologies dominate international research into the choice to teach, with qualitative approaches only found in 13 of 70 empirical articles examined in the scoping review carried out by Fray and Gore (2018). Narrative approaches offer expression of multiple and changing identities and this, although a time consuming methodology, allows teacher identity development to be considered alongside the sociocultural context in which these changes occur (Connelly and Clandinin, 1999; Søreide, 2006; Beauchamp and Thomas, 2009).

Analysis of Nimier defences of the self offers opportunities to uncover emotional aspects of self-concept and the relationship of self-identity and professional identity as a teacher which are recognised as important factors in teacher development and hence teacher recruitment and retention (Zembylas, 2003; Day, Kington, Stobart and Sammons, 2006; Rodgers and Scott, 2008).

To follow on from the research presented here there are two areas of particular interest that should be investigated further which could add considerably to the teacher recruitment debate worldwide:

- Our teachers influence subject choices. To what extent do they influence us in becoming teachers? This research suggests this relationship is more complex than much current literature suggests. 
- Can more systematic prior teaching experience, as opposed to the experience of being taught, increase participation in initial teacher education?

Acknowledgements: The authors thank the chemistry teacher participants for giving their time and sharing their 'chemistry teacher' stories. Also Ralph Levinson for his guidance and support throughout this research. They also wish to thank the reviewers for their very helpful and detailed guidance to support the revision of this paper.

\section{References}

Adriansen, H. K., and L. M. Madsen. 2009. Studying the making of geographical knowledge: The implications of insider interviews. Norsk Geografisk Tidsskrift - Norwegian Journal of Geography, 63 (3): 145-153.

Anthony, G. and K. Ord. 2008. Change-of-career secondary teachers: motivations, expectations and intentions, Asia-Pacific Journal of Teacher Education, 36 (4): 359-376. DOI: 10.1080/13598660802395865

Beauchamp, C. and L. Thomas. 2009. Understanding teacher identity: an overview of issues in the literature and implications for teacher education. Cambridge Journal of Education 39 (2): 175-189.

Bøe, M. V., E. K. Henriksen, T. Lyons and C. Schreiner. 2011. Participation in science and technology: young people's achievement-related choices in latemodern societies. Studies in science education 47 (1): 37-72.

Braun, V., and V. Clarke. 2006. Using thematic analysis in psychology. Qualitative Research in Psychology 3 (2): 77-101.

Brookhart, S. M., and D. J. Freeman. 1992. Characteristics of entering teacher candidates. Review of Educational Research, 62 (1): 37-60.

Brooks, C. 2016. Teacher subject identity in professional practice: Teaching with a professional compass. London: Routledge.

Connelly, M., and J. Clandinin. 1999. Shaping a professional identity: Stories of educational practice. London, ON: Althouse Press.

Cooper, J. and A. Alvarado. 2006. 'Preparation, recruitment and retention of teachers.' Accessed 25 October 2018. http://unesdoc.unesco.org/images/0015/001520/152023e.pdf . 
CooperGibson Research 2018. 'Factors affecting teacher retention: qualitative investigation Research report.' Accessed 25 October 2018. https://assets.publishing.service.gov.uk/government/uploads/system/uploads/at tachment_data/file/686947/Factors_affecting_teacher_retention__qualitative_investigation.pdf.

Day, C., A. Kington, G. Stobart and P. Sammons. 2006. The personal and professional selves of teachers: Stable and unstable identities. British Educational Research Journal, 32 (4): 601-616.

DfE. 2013. School Workforce Census. Accessed 25 October 2018. https://www.gov.uk/government/statistics/school-workforce-in-englnovember$\underline{2013}$

Eccles, J., T. F. Adler, R. Futterman, S. B. Goff, C. M. Kaczala, J. L. Meece and C. Midgley. 1983. "Expectancies, values and academic behaviours." In Acheivement and achievement motives: Psychological and sociological approaches, edited by J. T. Spence, 75-146. San Francisco: W. H. Friedman.

Fray, L., and J. Gore. 2018. Why people choose teaching: A scoping review of empirical studies, 2007-2016.Teaching and Teacher Education, 75:153-163. https://doi.org/10.1016/j.tate.2018.06.009.

Freud, S. 1964. "Inhibitions, symptoms and anxiety". In Standard edition of the complete psychological works of Sigmund Freud. 75-175.Translated and edited by J. Strachey. London: Hogarth Press.

Glutsch, N. and J. König. 2019. Pre-service teachers' motivations for choosing teaching as a career: does subject interest matter? Journal of Education for Teaching, 45 (5): 494-510, DOI: 10.1080/02607476.2019.1674560

Goodson, I. F., G. Biesta, M. Tedder and N. Adair. 2010. Narrative Learning. London: Routledge.

Guarino, C. M., L. Santibanez and G. A. Daley. 2006. Teacher recruitment and retention: A review of the recent empirical literature. Review of Educational Research. 76 (2):173-208.

Harris, K.-L., and F. Jensz. 2006. 'The preparation of mathematics teachers in Australia. Report prepared for the Australian Council of Deans of Science.' Accessed 25 October 2018.www. acds. edu. au/docs/Prep_Math_Teach_Aust. $p d f$. 
Heinz, M. 2013. Why choose teaching in the Republic of Ireland?-Student teachers' motivations and perceptions of teaching as a career and their evaluations of Irish second-level education. European Journal of Educational Studies. 5: 117.

Heinz, M. 2015. Why choose teaching? An international review of empirical studies exploring student teachers' career motivations and levels of commitment to teaching. Educational Research and Evaluation. 21 (3): 258-297.

Hillier, J., J. de Winter and J. Twidle. 2013. I Could Enjoy Teaching: The Case of Physics. Canadian Journal of Science, Mathematics and Technology Education., 13 (3) : 287-302.

Hollway, W., and T. Jefferson. 2000. Doing qualitative research differently. London: Sage.

Holmegaard, H.T. 2015. Performing a Choice-Narrative: A qualitative study of the patterns in STEM students' higher education choices. International Journal of Science Education, 37 (9) : 1454-1477.

Holmegaard, H. T., L. M. Madsen, and L. Ulriksen. 2012. To Choose or Not to Choose Science: Constructions of desirable identities among young people considering a STEM higher education programme. International Journal of Science Education, 36 (2): 186-215.

Holmegaard, H. T., L. M. Madsen, and L. Ulriksen. 2015. "A narrative approach to understand students' identities and choices." In Understanding Student Participation and Choice in Science and Technology Education: 31-42 edited by E. K. Henriksen, J. Dillon, and J. Ryder. London: Springer.

Howe, K. R., and M. S. Moses. 1999. Ethics in educational research. Review of research in education, 24: 21-59.

Jacobs, J. E. 2005. Twenty-five years of research on gender and ethnic differences in math and science career choices: What have we learned? New Directions for Child and Adolescent Development. 110: 85-94.

Kvale, S. 2006. Dominance through Interviews and Dialogues. Qualitative Inquiry, 12 (3): 480-500.

Lindqvist, P., U. K. Nordänger, and R. Carlsson. 2014. Teacher attrition the first five years - A multifaceted image. Teaching and Teacher Education, 40: 94-103.

Lortie, D. C. 2002. Schoolteacher: A sociological study. Chicago: University of Chicago Press. 
Malderez, A., A. J. Hobson, L.Tracey, and K. Kerr. 2007. Becoming a student teacher: Core features of the experience. European Journal of Teacher Education, 30 (3): 225-248. https://doi.org/10.1080/02619760701486068.

McLean, L., M. Taylor, and M. Jimenez. 2019. Career choice motivations in teacher training as predictors of burnout and career optimism in the first year of teaching. Teaching and Teacher Education, 85: 204-214.

McCrone, T., P. Rudd, P. Wade, and M. Walker. 2020. "Light Touch" Evaluation of the Student Associates Scheme". Leeds.Ac.Uk. http://www.leeds.ac.uk/educol/documents/00003887.htm.

Moore, A. 2004. The Good Teacher. London: Routledge.

Mujtaba, T., and M. Reiss. 2014. A survey of psychological, motivational, family and perceptions of physics education factors that explain 15-year-old students' aspirations to study physics in post-compulsory english schools. International Journal of Science and Mathematics Education. 12 (2):371-393.

Munro, M. and D. Elsom. 2000. Choosing science at 16: the influences of science teachers and careers advisors on students' decisions about science subjects and science and technology careers Cambridge: Careers Research and Advisory Centre.

Nimier, J. 1993. Defence Mechanisms against Mathematics. For the learning of mathematics. 13 (1): 30-34.

Ogunde, J. C., T. L. Overton, C. D. Thompson, R. Mewis, and S. Boniface. 2017. Beyond graduation: motivations and career aspirations of undergraduate chemistry students. Chemistry Education Research and Practice. 18 (3): $457-$ 471. doi:10.1039/C6RP00248J

Parfit, D. 1984. Reasons and persons: Oxford: Clarendon Press.

Powers, S. R. and K. K. Myers. 2017 Vocational Anticipatory Socialization: College Students' Reports of Encouraging/Discouraging Sources and Messages Journal of Career Development. 44 (5): 409-424

Priyadharshini, E., and A. Robinson-Pant. 2003. The attractions of teaching: An investigation into why people change careers to teach. Journal of Education for Teaching: International research and pedagogy, 29 (2): 95-112.

Redman, J., J. Montgomery, N. Critchlow, V. Fernandes, E. Hancock, J. Howie, and M. Macfarlane. 2013 What do graduates do? 2013 Accessed Oct.25, 2019. 
https://www.google.com/url?sa=t\&rct=j\&q=\&esrc=s\&source=web\&cd=\&ved $=2$ ahUKEwjh07KF5sfpAhXDQhUIHWuKCkcQFjABegQIAxAB\&url=https $\% 3 \mathrm{~A} \% 2 \mathrm{~F} \% 2$ Fluminate.prospects.ac.uk\%2Fmedia\%2F71780ba7-c66a-42aeadfd-b2be9931d798\%2Fwhat-do-graduates-do2013.pdf\&usg=AOvVaw0NFL9G_mHOVlkuF7huBvAb

Reid, I., and J. Caudwell. 1997. Why did secondary PGCE students choose teaching as a career? Research in Education 58: 46.

Reeves, T. D., and R. J. Lowenhaupt. 2016. Teachers as leaders: Pre-service teachers' aspirations and motivations. Teaching and Teacher Education, 57: 176-187. https://doi.org/10.1016/j.tate.2016.03.011

Richardson, P. W., and H. M. G. Watt. 2006. Who Chooses Teaching and Why? Profiling Characteristics and Motivations Across Three Australian Universities. Asia-Pacific Journal of Teacher Education, 34 (1): 27-56.

Rodd, M. 2010. Participation in undergraduate mathematics: choices and defences. Paper presented at the 16th Mathematical Views Conference, Tallinn.

Rodgers, C., and K. Scott. (2008). "The development of the personal self and professional identity in learning to teach." In Handbook of research on teacher education: Enduring questions and changing contexts. 732-755. edited by M. Cochran-Smith, S. Feiman-Nemser, D.J. McIntyre, and K.E. Demers. New York: Routledge.

Royal Society of Chemistry. 2014 Inspiring, engaging and expert: the formula for world-class science and chemistry education. Accessed 25 October 2018. http://www.rsc.org/globalassets/04-campaigningoutreach/campaigning/specialist- teachers-report.pdf

Segal, H. 2012. Introduction to the work of Melanie Klein. London: Karnac Books.

Sfard, A., and A. Prusak. 2005. Telling Identities: In Search of an Analytic Tool for Investigating Learning as a Culturally Shaped Activity. Educational Researcher. 34: 9.

Sheldrake, R. 2016. Confidence as motivational expressions of interest, utility, and other influences: Exploring under-confidence and over-confidence in science students at secondary school. International Journal of Educational Research 76: $50-65$. 
Søreide, G.E. 2006. Narrative construction of teacher identity: Positioning and negotiation. Teachers and Teaching: Theory and Practice, 12 (5): 527-547.

Stylianou, S. 2008. Interview control questions. International Journal of Social Research Methodology, 11 (3): 239-256.

Thomson, M.M., J.E. Turner, and J.L. Nietfeld. 2012. A typological approach to investigate the teaching career decision: Motivations and beliefs about teaching of prospective teacher candidates. Teaching and Teacher Education, 28 (3):324-335. doi:10.1016/j.tate.2011.10.007.

Thornton, M., P. Bricheno, and I. Reid. 2002. Students' reasons for wanting to teach in primary school. Research in Education, 67 (1): 33-43.

Waddell, M. 2002. Inside lives: Psychoanalysis and the growth of the personality. London: Karnac Books.

Watt, H. M. G., and P. W. Richardson. 2007. Motivational Factors Influencing Teaching as a Career Choice: Development and Validation of the FIT-Choice Scale. The Journal of Experimental Education. 75 (3): 167-202.

Watt, H. M. G., and P. W. Richardson. 2008. Motivations, perceptions, and aspirations concerning teaching as a career for different types of beginning teachers. Learning and Instruction, 18 (5): 408-428.

Watt, H. M. G., and P. W. Richardson. 2012. An introduction to teaching motivations in different countries: Comparisons using the FIT-Choice scale. Asia-Pacific Journal of Teacher Education, 40 (3): 185-197. https://doi.org/10.1080/1359866X.2012.700049.

Watt, H. M. G., P. W. Richardson, and J. Pietsch. 2007. Choosing to teach in the "STEM" disciplines: Characteristics and motivations of science, ICT, and mathematics teachers. Mathematics: Essential research, essential practice 2: 795-804.

Watt, H. M. G., P. W. Richardson, U. Klusmann, M. Kunter, B. Beyer, U. Trautwein and J. Baumert. 2012. Motivations for choosing teaching as a career: An international comparison using the FIT-Choice scale. Teaching and Teacher Education, 28 (6): 791-805. https://doi.org/10.1016/j.tate.2012.03.003.

Younger, M., S. Brindley, D. Pedder, and H. Hagger. 2004. Starting points: student teachers' reasons for becoming teachers and their preconceptions of what this will mean. European Journal of Teacher Education. 27 (3): 245-264. 
Zembylas, M. (2003). Caring for teacher emotion: Reflections on teacher self development. Studies in Philosophy and Education, 22:103-125. 